\title{
PERTANGGUNGJAWABAN HUKUM ATAS MALPRAKTIK OLEH TENAGA MEDIS BERDASARKAN UNDANG-UNDANG NOMOR 29 TAHUN 2004 TENTANG PRAKTIK KEDOKTERAN
}

\author{
oleh: \\ Fitri Nur Aryani \\ Antonia Intarti
}

\begin{abstract}
ABSTRAK
Undang-Undang Nomor 36 Tahun 2009 tentang Kesehatan pada dasarnya memberikan jaminan pemberian pelayanan kesehatan yang baik bagi masyarakat. Pemberian pelayanan kesehatan yang baik juga harus sesuai prosedur yang tercantum di dalam Undang-Undang Nomor 29 Tahun 2004 tentang Praktik Kedokteran. Tetapi, dalam suatu Hubungan antara Tenaga Kesehatan dan Pasien seringkali menimbulkan konflik karena pasien merasa dirugikan akibat kelalaian yang dilakukan Tenaga Kesehatan dalam menjalankan profesinya yang kemudian disebut sebagai Malpraktik Medis. Dalam penelitian ini penulis bertujuan meneliti dua permasalahan, yang pertama mengenai pertanggungjawaban hukum atas malpraktik oleh tenaga medis berdasarkan Undang-Undang Nomor 29 Tahun 2004 tentang Praktik Kedokteran dihubungkan dengan Undang-Undang Nomor 36 Tahun 2009 tentang Kesehatan, serta mengenai implikasi Hukum dalam penyelesaian kasus Malpraktik. Hasil penelitian ini menunjukan bahwa tenaga kesehatan dan rumah sakit dapat dimintakan tanggung jawab hukum, apabila melakukan kelalaian/kesalahan yang menimbulkan kerugian bagi pasien sebagai konsumen jasa pelayanan kesehatan yang diatur dalam pasal 58 ayat 1 UndangUndang Nomor 36 Tahun 2009 tentang Kesehatan. Pasien dapat menggugat tanggung jawab hukum kedokteran, dalam hal dokter berbuat kesalahan/kelalaian. Dokter tidak dapat berlindung dengan dalih perbuatan yang tidak sengaja, sebab kesalahan/kelalaian dokter yang menimbulkan kerugian terhadap pasien dapat menimbulkan hak bagi pasien untuk menggugat ganti rugi. Kemudian di dalam prosedur penyelesaian hukum, bentuk pengajuan gugatan menurut aturan hukum yang berlaku pula haruslah disertakan dengan pendapat hukum dari Majelis Kehormatan Disiplin Kedokteran Indonesia, yang di atur di dalam Undang-Undang Nomor 36 Tahun 2009 Tentang Kesehatan. Sebagaimana dalam bentuk pelaksanaannya harus mengikuti dasar dalam bentuk syarat hukum administrasi atau penyelesaian terhadap bentuk ketentuan secara kode etik profesi dalam praktik kedokteran yang sebagaimana pula diatur dalam Undang-Undang Nomor 29 Tahun 2004 Tentang Praktik Kedokteran. Bahwa perlindungan hukum atas profesi dokter sangatlah dijaga dan dilindungi serta bentuk dari keistimewaan profesi dokter sebagai jasa pelayanan medis.
\end{abstract}

Kata Kunci : Malpraktik, Pertanggungjawaban Hukum, Kedokteran

\section{PENDAHULUAN}

Kesehatan dapat didefinisikan sebagai suatu kondisi yang baik dan sempurna secara fisik dan mental. Hak atas kesehatan dijamin dalam Pasal $28 \mathrm{H}$ ayat (1) dan Pasal 34 ayat (3) dari Amandemen IV Undang-Undang Dasar 1945. Hak atas kesehatan diakui pula secara universal dalam berbagai instrument hukum hak asasi internasional, yaitu Pasal 25 (1) Deklarasi Universal Hak Asasi Manusia kemudian diatur dalam ketentuan yang lebih 
mengikat pada Pasal 12 Konvenan Hak Ekonomi Sosial dan Budaya. Undang-Undang kesehatan menyatakan bahwa semua warga Negara berhak memperoleh derajat kesehatan yang optimal. ${ }^{1)}$

Setiap warga Negara mempunyai hak yang secara konstitusi, yaitu hak untuk mendapat pekerjaan dan penghidupan yang layak sesuai dengan martabat manusia. Contohnya dalam pembangunan sosial-ekonomi di sebuah Negara, faktor yang mempengaruhi adalah kualitas lingkungan dan kesehatan masyarakatnya sehingga masyarakat sendiri yang menjadi modal dasar bagi sebuah Negara untuk bisa berkembang. Oleh karena itu maka setiap orang berkewajiban dalam ikut serta memelihara kesehatannya dan menyelenggarakan pembangunan kesehatan sebagai salah satu modal dasar pembangunan sebuah Negara.

Kerangka hukum kesehatan di Indonesia merupakan pola hubungan paternalistik, pola hubungan antara dokter (sebagai tenaga kesehatan yang utama) dan tenaga kesehatan lainnya dengan pasiennya merupakan pola hubungan paternalistik dan mengedepankan peranan dokter yang sangat dominan. Dokter berperan sebagai pihak yang mengambil keputusan terhadap semua tindakan kepada pasiennya. Hasil atau akibat dari tindakan dokter tersebut harus diterima oleh pasien, seakan-akan sudah menjadi tanggung jawab pasien. Pasien diminta untuk menerima setiap akibat dari tindakan dokter karena adanya anggapan bahwa dokter pasti telah menentukan dan melakukan yang terbaik bagi pasien. ${ }^{2)}$

Banyak ditemukan keadaan di mana pasien sampai melakukan upaya-upaya di bidang hukum maupun pengaduan kepada Majelis Kehormatan Disiplin Kedokteran Indonesia (MKDKI) apabila merasa dirugikan oleh dokter. Jumlah pengaduan ke MKDKI Tahun 2006Juli 2017 sebanyak 381 pengaduan. ${ }^{3)}$

Adanya perubahan dalam hubungan antara dokter dengan pasien terjadi karena banyak faktor-faktor, antara lain:

a. Kepercayaan tidak lagi tertuju kepada dokter secara pribadi, akan tetapi kepada keampuhan ilmu dan teknologi kesehatan.

b. Masyarakat menganggap tugas dokter tidak hanya menyembuhkan tetapi juga perawatan.

c. Ada kecenderungan untuk menyatakan bahwa kesehatan bukan lagi merupakan keadaan tanpa penyakit, akan tetapi lebih berarti kesejahteraan fisik, mental, dan sosial.

d. Semakin banyak peraturan yang memberikan perlindungan hukum kepada pasien, sehingga semakin mengetahui dan memahami hak-hak nya dalam hubungan masyarakat.

e. Tingkat kecerdasan masyarakat mengenai kesehatan semakin meningkat. ${ }^{4}$

Istilah malpraktik atau malpractice, atau malapraxis dari sudut harfiah, memiliki pengertian praktik yang buruk, praktik yang jelek. ${ }^{5)}$ Malpraktik atau dikenal juga dengan istilah malpraxis, secara umum berarti praktik yang buruk. Istilah malpraktik dapat ditujukan

\footnotetext{
1) Fred Ameln, Kapita Selekta Hukum Kedokteran, Grafika Tamajaya, Jakarta, 1991, hlm.14.

2) Sri Siswati, Etika dan Hukum Kesehatan: Dalam Perspektif Undang-Undang Kesehatan, Rajawali Pers, Jakarta, 2015, hlm.2.

3)Zaura "Tata Laksana Pengelolaan Kasus Pelanggaran Disiplin Kedokteran”,http://www.kki.go.id/assets/data/menu/ZA-Alur Pengaduan Medan 1 Agust 2017. .pdf, diunduh pada 7 Februari 2019.

4) Soerjono Soekanto, Aspek Hukum Kesehatan (suatu kumpulan catatan), Ind Hill Co, Jakarta, 1989, hlm.150

${ }^{5)}$ Hermin Hadijati Koeswadji, Hukum Dokter Studi tentang Hubungan Hukum dalam mana Dokter sebagai Salah satu pihak, PT Citra Aditya Bakti, Bandung, 1998, hlm.123.
} 
terhadap orang yang menjalankan profesinya dengan menggunakan cara atau ilmunya secara tidak wajar.

Tindakan malpraktik, pada dasarnya terjadi karena adanya unsur kelalaian yang dilakukan dokter dalam melaksanakan praktik kedokteran, sedangkan tindakan dokter dilakukan secara sadar dengan tujuan yang sudah terarah pada akibat yang hendak ditimbulkan atau tidak peduli terhadap akibatnya, walaupun ia mengetahui atau seharusnya mengetahui bahwa tindakannya itu adalah bertentangan dengan hukum yang berlaku, tidak termasuk dalam kategori tindak malpraktik. Perbuatan dokter yang dilakukan dengan sengaja dan terarah pada tujuan yang bertentangan dengan hukum termasuk ke dalam tindak kriminal/kejahatan, misalnya: aborsi tanpa alasan yang tepat, euthanasia dan sebagainya.

Kelalaian merupakan suatu tindakan kurang teliti, kurang hati-hati dan ketidaksengajaan yang dilakukan dalam melakukan suatu perbuatan. Dalam perbuatan tersebut, pelaku tidak memiliki motif atau tujuan untuk menimbulkan akibat yang terjadi. Akibat yang ditimbulkan tersebut disebabkan karena adanya kelalaian yang sebenarnya terjadi diluar kehendaknya. Apabila dipandang dari sudut hukum perdata, peristiwa malpraktik dapat disebabkan karena dua faktor, yaitu dokter melakukan perbuatan wanprestasi atau cedera janji dan perbuatan melawan hukum. Tindakan malpraktik ini, ada kalanya terjadi dalam pelayanan kesehatan, contohnya: kekeliruan dalam mendiagnosis, kesalahan dalam anastesi, melakukan tindakan pelayanan medis yang tidak sesuai dengan standar prosedur dan lain sebagainya.

Upaya Pemerintah Indonesia untuk memberikan perlindungan serta kepastian hukum bagi pasien maupun dokter terkait malpraktik adalah dengan diterbitkannya Peraturanperaturan antara lain Undang-undang Nomor 29 Tahun 2004 tentang Praktik Kedokteran, Undang-undang Nomor 36 Tahun 2009 tentang Kesehatan, Peraturan Menteri Kesehatan RI Nomor 1419/Menkes/Per/X/2005 tentang Penyelenggaraan Praktik Dokter dan Dokter Gigi. Peraturan Menteri Kesehatan RI Nomor 434/Menkes/SK/X/1983 tentang Berlakunya Kode Etik Dokter Indonesia bagi Para Dokter di Indonesia, dan Peraturan Menteri Kesehatan RI Nomor 585/Menkes/Per/IX/1989 tentang Persetujuan Tindakan medik.

Undang-undang Nomor 36 Tahun 2009 tentang Kesehatan pada dasarnya memberikan jaminan pemberian pelayanan kesehatan yang baik bagi masyarakat, hal ini tercantum dalam Pasal 1, yang membagi pelayanan kesehatan menjadi lima jenis, terdiri dari pelayanan kesehatan promotif, preventif, kuratif, rehabilitative, dan pelayanan kesehatan tradisional. Tiap pelayanan kesehatan yang akan diberikan oleh tenaga kesehatan ditentukan secara mandiri oleh pihak pasien sebagaimana yang tertuang dalam Pasal 5 ayat (3) Undang-undang Kesehatan.

Hubungan antara dokter dan pasien seringkali menimbulkan konflik. Pasien sering merasa dirugikan apabila dokter tidak dapat menyembuhkan, atau memulihkan gangguan kesehatan. Melihat dari sisi yang lain, dokter juga merasa telah melakukan tindakan yang sesuai dan baik, walaupun pada akhirnya dokter tidak berhasil mengobati pasien. Selanjutnya apabila pasien tidak mendapatkan apa yang diharapkannya maka pasien menganggap bahwa dokter melakukan kesalahan atau kelalaian.

Berdasarkan hal tersebut penulis mengambil contoh kasus pada putusan No. 96/Pdt/2017/PT.Bdg, di mana kasus tersebut bermula dari tidak profesionalnya Rumah Sakit Karya Husada Cikampek atas tindakan medis yang dilakukan terhadap pasien tanpa menggunakan hal-hal yang sesuai dengan Standar Operasional Prosedur Tindakan Medis atau Tindakan Praktik Kedokteran. Akibat dari tidak memadainya sarana dan prasarana atas fasilitas operasional rumah sakit perbuatan atau tindakan tersebut mengakibatkan pasien 
mengalami pembusukan pada daging bagian kedua betis kaki kanan dan kaki kiri yang terjadi karena menumpuknya kapas atau kain kasa yang tidak steril, pemberian darah yang tidak sesuai dengan golongan darah pasien serta tindakan operasi bedah pertama dan kedua tersebut membuat kondisi pasien semakin parah dan sangat memperihatinkan.

Kerugian yang dialami pasien tidak hanya ditimbulkan dari tindakan atas operasi bedah tetapi juga ditimbulkan atas tindakan perawatan medis yang dilakukan oleh bukan Tenaga Medis atau Tenaga ahli medis tetapi malah ada beberapa tindakan yang dilakukan dengan menyertakan office boy sebagai pelaku medis. Hal ini jelas bahwa tindakan pihak Rumah Sakit serta dokter tersebut sudah dapat dikatakan sebagai tindakan Malpraktik dan Perbuatan Melawan Hukum atas tindakan yang tidak sesuai dengan Standar operasional prosedur serta melanggar ketentuan-ketentuan hukum yang berlaku di dalam Praktik Kedokteran.

Kasus selanjutnya yang ingin penulis analisis adalah peristiwa yang dialami oleh Sunti Suprapti perempuan asal Tambakromo, Blora, Jawa Tengah. Sunti melakukan persalinan di Puskesmas Cepu pada Bulan Maret 2018. Setelah melakukan persalinan Sunti terpaksa harus menjalani pembedahan usai operasi persalinan normal. Pembedahan dilakukan, karena didalam alat vital Sunti terdapat jarum bekas jahitan luka persalinan yang tertinggal. Sewaktu melakukan jahit usai persalinan Bidan tersebut mengira bahwa patahan jarum jatuh ke lantai, tetapi ternyata masih tertinggal di alat vital Sunti hingga Sunti harus menjalankan operasi lagi di Rumah Sakit Umum Cepu.

\section{B. Identifikasi Masalah}

1. Bagaimana pertanggungjawaban hukum atas malpraktik oleh tenaga medis berdasarkan Undang-Undang Nomor 29 Tahun 2004 Tentang Praktik Kedokteran dihubungkan dengan Undang-Undang Nomor 36 Tahun 2009 Tentang Kesehatan?

2. Bagaimana Implikasi Hukum Pada Prosedur Penyelesaian Kasus Malpraktik?

\section{TINJAUAN PUSTAKA}

Tanggungjawab Hukum dalam Hukum Perdata berupa Tanggungjawab seseorang terhadap perbuatan yang melawan hukum. Perbuatan melawan hukum tidak hanya mencakup perbuatan yang bertentangan dengan undang-undang pidana saja, akan tetapi jika perbuatan tersebut bertentangan dengan undang-undang lainnya dan bahkan dengan ketentuan-ketentuan hukum yang tidak tertulis. Ketentuan perundang-undangan dari perbuatan melawan hukum bertujuan untuk melindungi dan memberikan ganti rugi kepada pihak yang dirugikan. ${ }^{6}$

Menurut Pasal 1365 K.U.H Perdata, maka yang dimaksud dengan perbuatan melanggar hukum adalah perbuatan yang melawan hukum yang dilakukan oleh seseorang yang karena salahnya telah menimbulkan kerugian bagi orang lain. Terdapat tiga kategori perbuatan melawan hukum, yaitu sebagai berikut: ${ }^{7)}$

a. Perbuatan melawan hukum karena kesengajaan

b. Perbuatan melawan hukum tanpa kesalahan (tanpa unsur kesengajaan maupun kelalaian)

\footnotetext{
6) Komariah, Edisi Revisi Hukum Perdata, Universitas Muhammadiyah Malang, 2001, hlm 12.

7) Moegni, Djojodirdjo, Perbuatan Melawan Hukum:tanggung gugat untuk kerugian yang disebabkan karena perbuatan melawan hukum), Jakarta, Pradnya Paramita, 1997
} 
C. Perbuatan melawan hukum karena kelalaian

Maka model tanggung jawab hukum adalah sebagai berikut: ${ }^{8)}$

a. Tanggung jawab dengan unsur kesalahan (kesengajaan dan kelalaian) sebagaimanapun terdapat dalam Pasal 1365 K.U.H Perdata, yaitu : "tiap-tiap perbuatan melanggar hukum yang membawa kerugian kepada orang lain, mewajibkan orang yang karena salahnya menerbitkan kerugian itu, mengganti kerugian tersebut".

b. Tanggung jawab dengan unsur kesalahan khususnya kelalaian sebagaimana terdapat dalam Pasal 1366 K.U.H Perdata yaitu: "setiap orang bertanggungjawab tidak saja untuk kerugian yang disebabkan perbuatannya, tetapi juga untuk kerugian yang disebabkan kelalaian atau kurang hati-hatinya".

C. Tanggung jawab mutlak (tanpa kesalahan) sebagaimana terdapat dalam Pasal 1367 K.U.H Perdata yaitu:

1) Seseorang tidak saja bertanggung jawab untuk kerugian yang disebabkan karena perbuatannya sendiri, tetapi juga untuk kerugian yang disbebabkan karena perbuatan orang-orang yang menjadi tanggungannya atau disebabkan oleh barangbarang yang berada dibawah pengawasannya;

2) Orang tua dan wali bertanggung jawab tentang kerugian, yang disebabkan oleh anak-anak belum dewasa, yang tinggal pada mereka dan terhadap siapa mereka melakukan kekuasaan orang tua dan wali;

3) Majikan-majikan dan mereka yang mengangkat orang-orang lain untuk mewakili urusan-urusan mereka, adalah bertanggung jawab tentang kerugian yang diterbitkan oleh pelayan-pelayan atau bawahan-bawahan mereka di dalam melakukan pekerjaan untuk mana orang-orang ini dipakainya;

4) Guru-guru sekolah dan kepala-kepala tukang bertanggung jawab tentang kerugian yang diterbitkan oleh murid-murid dan tukang-tukang mereka selama waktu orang-orang ini berada dibawah pengawasan mereka;

5) Tanggung jawab yang disebutkan diatas berakhir, jika orangtua, wali, guru sekolah dan kepala-kepala tukang itu membuktikan bahwa mereka tidak dapat mencegah perbuatan untuk mana mereka seharusnya bertanggung jawab.

\section{PEMBAHASAN}

\section{A. Pertanggungjawaban Hukum Atas Malpraktik Oleh Tenaga Medis Berdasarkan Undang-Undang Nomor 29 Tahun 2004 tentang Praktik Kedokteran Dihubungkan Dengan Undang-Undang Nomor 36 Tahun 2009 Tentang Kesehatan}

Sebagaimana tercantum didalam Undang-Undang Nomor 29 Tahun 2006 tentang Praktik Kedokteran disebutkan dalam Pasal 66 ayat (1) Undang-Undang Praktik Kedokteran, diatur suatu keadaan di mana terjadi kesalahan yang melibatkan pelayanan kesehatan dalam hal ini oleh dokter, maka yang dapat mengajukan pengaduan kepada Ketua Majelis Kehormatan Disiplin Kedokteran Indonesia (MKDKI) adalah setiap orang yang mengetahui atau kepentingannya dirugikan.

Bahwa dalam hal ini pula terkait pembahasan mengenai seorang pasien yang dirugikan, apabila di hubungkan dengan suatu aturan hukum lainnya maka hal itu dapat merujuk kepada

${ }^{8)}$ www.oocities.org/ilmuhukum/babii.doc, di akses pada tanggal 29 Juni 2019 pukul 06.05 
ketentuan mengenai pasien sebagai konsumen. Dalam hal ini pengertian pasien/konsumen tersebut diatur didalam Undang-Undang Nomor 8 Tahun 1999 tentang Perlindungan Konsumen, yang menyebutkan yaitu bahwa setiap orang pemakai barang dan jasa yang tersedia dalam masyarakat, baik bagi kepentingan diri sendiri, keluarga, orang lain, maupun mahkluk hidup lain dan tidak untuk diperdagangkan, misalnya produk yang berupa barang contohnya obat-obatan, suplemen, dll. Serta dengan produk yang berupa jasa contohnya jasa pelayanan kesehatan yang diberikan oleh dokter, dokter gigi, dan jasa asuransi pelayanan kesehatan.

Maka berdasarkan hal tersebut disamping dapat mengadukan kerugian yang dideritanya kepada Majelis Kehormatan Disiplin Kedokteran Indonesia, menurut Pasal 66 ayat (3) Undang-Undang Praktik Kedokteran, korban malpraktik yang dirugikan atas kesalahan atau kelalaian dokter dalam melakukan tindakan medis juga dapat melaporkan adanya dugaan pidana kepada pihak yang berwenang dan/atau menggugat kerugian secara perdata ke pengadilan.

Selanjutnya, disebutkan pula dalam Pasal 67 dan Pasal 68 Undang-Undang Praktik Kedokteran bahwa Majelis Kehormatan Disiplin Kedokteran juga berwenang untuk memeriksa dan memutus keputusan atas pengaduan yang diterima. Apabila ditemukan adanya pelanggaran etika yang berdasarkan pada bentuk aturan dan ketentuan didalam KODEKI maka Majelis Kehormatan Kedokteran yang akan meneruskan pengaduan pada organisasi profesi.

Jadi, merujuk kepada ketentuan pada Pasal 66 ayat (3) Undang-Undang tentang Praktik Kedokteran tersebut menjelaskan bahwa bentuk upaya perlindungan hukum terhadap korban malpraktik, yang berdasarkan dengan hak kepada korban malpraktik untuk melakukan upaya hukum atas bentuk segala ganti kerugian yang dialami oleh korban. Maka penjelasan atas hal tersebut di hubungkan dengan kasus malpraktik yang terjadi di Rumah Sakit Karya Husada Cikampek terhadap salah satu pasiennya yang secara garis besar bahwa bentuk pelayanan medis yang dilakukan oleh tenaga medis sangat tidak sesuai dan tidak menerapkan prinsipprinsip pelayanan medis berdasarkan Standart Operating Procedure Kedokteran, jadi atas kejadian itu pula pasien atau korban mengalami cacat di salah satu bagian tubuhnya.

Pada Pasal 29 Undang-Undang Nomor 36 Tahun 2009 tentang Kesehatan, dikatakan bahwa dalam hal tenaga kesehatan diduga melakukan kelalaian dalam menjalankan profesinya, kelalaian tersebut harus diselesaikan terlebih dahulu melalui mediasi. Pada kasus pertama berdasarkan Putusan Nomor 96/PDT/2017/PT.BDG tidak dikatakan bahwa telah dilakukan mediasi oleh kedua belah pihak. Namun, ketika gugatan telah masuk ke pengadilan, maka sesungguhnya Hakim atau Majelis Hakim wajib mengupayakan mediasi terhadap kedua belah pihak agar diperoleh perdamaian, sepanjang persidangan berlangsung.

Mengacu pada Pasal 53 Undang-Undang Nomor 36 Tahun 2009 tentang Kesehatan, dikatakan bahwa pelayanan kesehatan perseorangan ditujukan untuk menyembuhkan penyakit dan memulihkan kesehatan perseorangan dan keluarga. Pada kasus yang menimpa Sri Lestari terlihat bahwa setelah operasi pertama dirasakan ada kelainan dan badan menggigil sehingga Dokter yang menangani Sri Lestari menyarankan agar dilakukan operasi kedua, bahkan setelah dilakukan operasi kedua kondisi Sri Lestari semakin memburuk dengan dibuktikan oleh bau busuk yang berasal dari kedua betis kaki Sri Lestari. Lalu pada kasus yang menimpa Sunti Suprapti dikatakan bahwa setelah persalinan dilakukan, alat vital sunti terasa nyeri karena ada jarum jahit yang tertinggal di dalam organ intimnya. Sementara Dokter dari Rumah 
Sakit Cepu menganggap bahwa tertinggalnya barang setelah dilakukan operasi merupakan hal yang wajar.

Pada Pasal 54 Undang-Undang Kesehatan, dikatakan bahwa penyelenggaraan pelayanan kesehatan dilaksanakan secara bertanggung jawab, aman, bermutu, serta merata dan tidak diskriminatif. Pada kasus Sri Lestari dan Sunti Suprapti dapat kita lihat bahwa dokter yang telah melakukan tindakan kedokteran dituntut untuk bertanggung jawab dan pada akhirnya bertanggung jawab sesuai dengan porsi/batasnya masing-masing.

Pada Pasal 58 Undang-undang nomor 36 tahun 2009 tentang Kesehatan dikatakan bahwa setiap orang berhak menuntut ganti rugi terhadap seseorang, tenaga kesehatan, dan/atau penyelenggara kesehatan yang menimbulkan kerugian akibat kesalahan atau kelalaian dalam pelayanan kesehatan yang diterimanya. Pada kasus, dapat kita lihat bahwa Sri Lestari dan Sunti Suprapti telah menggunakan haknya sebagai pasien yang merasa dirugikan oleh tenaga kesehatan yang melakukan tindakan kedokteran terhadapnya dengan menuntut dokter yang bersangkutan, karena dokter bersangkutan diduga telah melakukan tindakan kedokteran yang tidak sesuai dengan standar profesi kedokteran.

Kompetensi atas hak-hak yang harus dituntut adalah dengan munculnya kerugian seseorang tersebut dan jelas menjadi bentuk dasar pada pokok perkara dalam sudut pandang hukum perdata di dalam pengajuan atas gugatan suatu perkara penyelesaian sengketa pada prosedur persidangan perdata baik secara tuntutan ganti kerugian maupun wanprestasi.

\section{B. Implikasi Hukum Pada Prosedur Penyelesaian Kasus Malpraktik}

Mengacu pada ketentuan yang tercantum didalam Pasal 29 Undang-Undang Kesehatan bahwa dalam hal tenaga kesehatan diduga melakukan kelalaian dalam menjalankan profesinya, kelalaian tersebut harus diselesaikan terlebih dahulu melalui mediasi. Hal ini sangat bertentangan dengan ketentuan yang pada pasalnya dalam pertimbangan dasar tersebut tidak diperjelaskan mengenai hal ke badan apa mengenai mediasi itu dilaksanakan.

Apabila dilihat dari ketentuan daripada prosedur penyelesaian dalam penanganan kasus oleh MKDKI diatur didalam Peraturan Konsil Kedokteran Indonesia Nomor 2 Tahun 2011 tentang Tata Cara Penanganan Kasus Dugaan Pelanggaran Disiplin Dokter dan Dokter Gigi. Penanganan atas kasus dugaan pelanggaran tersebut dilakukan setelah adannya pengaduan yang dilakukan langsung oleh pasien.

Mengikuti aturan lanjutan dari pada ketentuan tersebut menjelaskan pula syarat pengaduan tersebut terdapat didalam Pasal 3 Peraturan Konsil Nomor 2 Tahun 2011. Setelah pengaduan terdaftar di MKDKI/MKDKI-P maka pihak pengadu dapat memberikan data pendukung pengaduan berupa alat bukti yang dimiliki dan pernyataan tentang kebenaran pengaduan.

Setelah itu akan dilakukan klarifikasi serta penanganan kasus yang berupa pemeriksaan awal, pada tahap ini didasarkan pada Pasal 13, hingga Pasal 18 Peraturan Konsil Nomor 2 Tahun 2011. Maka selanjutnya kewenangan dari MKDKI adalah memutuskan pengaduan tersebut tidak dapat diterima, ditolak atau penghentian sementara dalam pemeriksaan.

Memperjelas kembali pada prosedur penyelesaian kasus malpraktik dengan berdasarkan bentuk investigasi serta kajian yang dilakukan tertutup oleh tim khusus yang dibentuk oleh MKDKI. Sehingga didalam sidang pemeriksaan disiplin dokter atau dokter gigi selesai, maka Majelis Pemeriksaan Disiplin (MPD) akan menetapkan keputusan terhadap yang bersangkutan (dokter/tenaga medis). Selanjutnya pemberian sanksi disiplin yaitu berupa sebuah Peringatan Tertulis, kewajiban untuk mengikuti pelatihan atau pendidikan yang dapat 
dilakukan dalam bentuk Reeduksi Formal maupun Reeduksi Non-Formal, serta pencabutan atas STR atau SIP yang bersifat sementara 1 tahun atau tetap/selamanya dan/atau pembatasan tindakan asuhan medis tertentu pada suatu area ilmu kedokteran dalam pelaksaan praktik kedokteran.

Maka apabila terbukti melakukan pelanggaran disiplin, setelah keluarnya suatu keputusan atas dokter atau dokter gigi yang diadukan dapat mengajukan keberatan terhadap keputusan MKDKI, selanjutnya kepada Ketua MKDKI dalam waktu selambat-lambatnya 30 hari sejak keputusan tersebut dibacakan atau diterimanya keputusan tersebut dengan mengajukan bukti baru yang mendukung keberatannya.

Penjelasan dalam hal ini menjelaskan yaitu mengenai netralitas MKDKI, pada Pasal 59 ayat (1) Undang-Undang Praktik Kedokteran, disebutkan bahwa MKDKI terdiri atas 3 (tiga) orang dokter dan 3 (tiga) orang dokter gigi dari organisasi masing-masing, seorang dokter dan seorang dokter gigi mewakili asosiasi Rumah Sakit dan 3 (tiga) orang sarjana hukum, sehingga dalam hal ini pula menjadi hal yang jelas tidak dikhawatirkan lagi pihak dokter akan membela rekan sejawatnya.

Beberapa kasus yang diajukan ke pengadilan masih terdapat kesulitan dalam menentukan terjadinya malpraktik atau tidak, karena dalam tatanan hukum Indonesia belum diatur mengenai standar profesi dokter sehingga hakim cenderung berpatokan pada hukum acara konvensional, sedangkan dokter merasa sebagai seorang professional yang tidak mau disamakan dengan hukuman bagi pelaku kriminal biasa, misalnya pencurian atau pembunuhan.

Akan tetapi mengacu kepada ketentuan atas pelanggaran hukum, bagi seseorang yang berprofesi sebagai dokter, dan benar-benar melakukan tindakan atas dasar bentuk kelalaian atau kesengajaan atau malpraktik seharusnya dapat dilakukan bentuk sanksi secara perdata maupun pidana. Hal ini mengacu kepada bentuk dari pada penjelasan atas asas hukum atau doktrin yang berlaku diantaranya adalah asas Res Ipsa Loquitur.

Berdasarkan asas Res Ipsa Loquitur kelalaian dalam suatu tindakan medis dapat langsung dibuktikan didalam Pengadilan, cara yang dapat dipakai untuk membuktikan adanya kesalahan/kelalaian dokter dalam malpraktik medik dengan mencari fakta yang dapat secara tidak langsung yang membuktikan adanya kesalahan dokter. Doktrin Res Ipsa Loquitor dapat diterapkan apabila fakta-fakta yang ditemukan memenuhi kriteria antara lain fakta yang tidak mungkin terjadi jika dokter tidak lalai kemudian fakta yang terjadi berada di bawah tanggung jawab dokter,serta pasien tidak ikut menyumbang adanya fakta itu. Seharusnya hak imunitas profesi dokter yang hanya dikenakan sanksi kode etik saja tidak cukup, apalagi sudah jelas ada kelalaian yang mengakibatkan kerugian pada pasien. Karena, penerapan Doktrin Res Ipsa Loquitor akan membawa konsekuensi yuridis yaitu lebih memberikan keadilan artinya dirasakan sangat tidak adil manakala pihak korban dari perbuatan melawan hukum harus menanggung sendiri suatu kerugian yang sebenarnya merupakan akibat dari kelalaian orang lain.

Karena pihak lain tersebut, yang sebenarnya lebih tahu kejadiannya, tetapi tidak mau menjelaskan apa yang sebenarnya terjadi sementara pihak korban memang tidak mengetahui kejadiannya secara persis karena tidak memiliki akses pada kejadian tersebut, sehingga di Pengadilan tidak bisa membuktikan kesalahan pelaku perbuatan melawan hukum tersebut. Pihak korban tidak perlu membuktikan kesalahan pelaku, tetapi cukup membeberkan akibat yang terjadi padanya, dan bagaimana sampai akibat tersebut terjadi serta membuktikan bahwa biasanya akibat seperti itu baru terjadi jika ada kelalaian dari pihak pelaku perbuatan melawan hukum tersebut. Lalu, merupakan presumsi kelalaian artinya dengan hanya membeberkan 
suatu akibat dan fakta yang menimbulkan akibat tersebut oleh hukum telah dipresumsi bahwa pihak yang disangka pelaku perbuatan melawan hukum dianggap telah melakukannya dengan kelalaian.

Hal tersebut yang menjadi dasar bagi kalangan masyarakat yang semakin kritis akan hak-hak kesehatannya. Persoalan yang muncul adalah mengenai obyektifitas dan kenetralan dari para dokter yang karena pengetahuan, pengalaman dan keahliannya diminta memberikan pendapatnya sebagai ahli di pengadilan. Di satu sisi, dokter sebagai professional, tentu mengetahui kewajibannya untuk menjalankan profesinya dengan sebaik-baiknya dan melakukan profesi sesuai dengan standar yang dikualifikasikan secara umum (lege artis), namun di sisi lain tidak dapat dipungkiri bahwa setiap dokter adalah bagian dari sebuah komunitas professional sehingga kecenderungan untuk membela korps dan sesamanya dalam profesi sangat tinggi. Pada saat ini dengan adanya peradilan umum saja pembelaan korps dan prfoesi sudah sangat luar biasa maraknya, apalagi jika dibentuk peradilan profesi khusus. Jika dalam suatu kasus malpraktik, doktrin res ipsa loquitur dapat diterapkan, maka pada dasarnya hakim tidak akan mengalami kesulitan untuk memutus dan mengadili perkara karena kebenaran dicapai tanpa suatu pembuktian yang rumit. Namun, jika doktrin tersebut tidak dapat diterapkan, maka pembuktian secara medis adalah hal yang sangat fundamental untuk dilakukan, dan dalam hal ini maka hakim akan sangat tergantung pada obyektivitas dan kejelasan keterangan yang diberikan oleh ahli.

\section{PENUTUP}

\section{Kesimpulan}

Bahwa hasil akhir suatu pengobatan atas tindakan medis sangat tergantung dari banyak faktor, karena itu tidak setiap tindakan medis yang mengakibatkan kematian atau cacat berat disebut Malpraktik. Maka bentuk daripada Malpraktik harus benar-benar memenuhi unsur dari pada syarat atas kategori dari ruang lingkup Malpraktik itu sendiri. Diantaranya bentuk Pelanggaran Hukum Pidana dan bentuk pelanggaran Hukum Perdata. Pembahasan pada sudut pandang Hukum Perdata, tercantum pada Pasal 1365, Pasal 1366 dan Pasal 1367. Bentuk perlindungan korban apabila tenaga medis diduga melakukan kelalaian atau malpraktik juga tercantum dalam Pasal 58 Undang-Undang Nomor 36 Tahun 2009 tentang Kesehatan dan Pasal 66 Undang-Undang Nomor 29 Tahun 2004 tentang Praktik Kedokteran.

Berdasarkan hal yang diduga telah melakukan kelalaian atau kesalahan dalam melakukan tindakan atas pelayanan medis maka diselesaikan terlebih dahulu untuk tidak diproses melalui jalur hukum, tetapi diserahkan atau dimintakan dahulu pendapat dari Majelis Kehormatan Disiplin Kedokteran Indonesia, hal ini di atur didalam Undang-Undang Nomor 36 Tahun 2009 Tentang Kesehatan. Sehingga dalam bentuk pelaksanaannya harus mengikuti dasar dalam bentuk syarat hukum administrasi atau penyelesaian terhadap bentuk ketentuan secara kode etik profesi dalam praktik kedokteran yang sebagaimana pula diatur dalam Undang-Undang Nomor 29 Tahun 2004 Tentang Praktik Kedokteran. Maka dalam hal ini penjelasan aturan hukum yang berlaku sangat menjelaskan bahwa perlindungan hukum atas profesi dokter sangatlah dijaga dan dilindungi secara penuh, serta benar-benar menjaga bentuk dari keistimewaan profesi dokter sebagai jasa pelayanan medis. 


\section{Saran}

Pasien sebagai konsumen pelayanan kesehatan, sebaiknya mengetahui hak dan kewajibannya yang tercantum di dalam Undang-Undang Nomor 36 Tahun 2009 tentang Praktik Kedokteran sehingga apabila ada hal yang tidak sesuai dengan peraturan yang tercantum maka bisa dipertanyakan kepada dokter yang bersangkutan. Apabila terdapat dugaan malpraktik sebaiknya pasien melaporkan terlebih dahulu kepada MKDKI. Jika dari MKDKI pasien merasa kurang puas, maka bisa digugat secara pidana maupun perdata dengan alat bukti yang kuat.

Prosedur penyelesaian kasus malpraktik hendaknya lebih jelas lagi, karena banyak korban yang merasa bahwa penyelesaian melalui MKDKI masih memihak kepada tenaga medis yang bersangkutan, karena tidak adanya netralitas dan adanya pembelaan untuk rekan sejawat satu profesi yang terkadang lebih diutamakan. Dalam proses persidangan pun, ketika korban yang dirugikan itu memang dalam keadaan yang parah seharusnya hakim sudah bisa menggunakan doktrin Res Ipsa Loquitoir.

\section{DAFTAR PUSTAKA}

Djojodirdjo, Perbuatan Melawan Hukum:tanggung gugat untuk kerugian yang disebabkan karena perbuatan melawan hukum, Pradyna Paramita, Jakarta, 2007

Komariah, Edisi Revisi Hukum Perdata, Universitas Muhamadiyah Malang, Malang, 2001 Munandar Wahyudin, Hukum Kedokteran, Alfabeta, Bandung, 2017 